\title{
A COMPORATIVE ANALYSIS OF THE SOCIO-ECONOMIC DEVELOPMENT OF ROMANIAN CITIES AND TOWNS INHABITED BY ETHNIC HUNGARIANS
}

\author{
Zoltán MEGYESI ${ }^{\mathrm{a}}$, Márton PÉTI ${ }^{\mathrm{b}}$ \\ ${ }^{a}$ Research Institute for National Strategy, Budapest, Hungary. E-mail: zoltan.megyesi@nski.gov.hu \\ b Research Institute for National Strategy, Corvinus University of Budapest GEO Institute Geography, \\ Geoeconomy and Sustainable Development, Budapest, Hungary. E-mail: marton.peti@nski.gov.hu
}

Cite this article: Megyesi Z., Péti, M. (2019). A comparative analysis of the socio-economic development of Romanian cities and towns inhabited by ethnic Hungarians. Deturope. 11(3), 205-228.

\begin{abstract}
The aim of this study is to examine the socio-economic development of all Romanian cities and towns with a Hungarian majority. Socio-economic indicators of these settlements with a strong ethnic Hungarian character were compared to similar other cities of Romania having an ethnic Romanian majority. This research examined the general socio-economic development of these settlements, as well as some components of this socio-economic development through seven complex indicators calculated from 25 indicators (per unit indicators). According to the results, cities and towns with a Hungarian majority are relatively heterogeneous. The major cities of Szeklerland have higher development level than most of the examined Romanian settlement. However, the small sized towns with a Hungarian majority along the western border of Romania have lower values than the similar settlements in their neighborhood with an ethnic Romanian majority or the small and medium sized Hungarian towns of Szeklerland.
\end{abstract}

Keywords: urban development, Romanian urbanization, Transylvanian urbanization, Hungarian minority, ethnic diversity, ethnic minorities, ethnic development

\section{INTRODUCTION}

According to recent censuses, countries neighbouring Hungary are inhabited by altogether 2 million ethnic Hungarians. Out of this 1.2 million live in Romania (INSSE, 2011). The native Hungarian minority communities of Romania can be found almost exclusively in Transylvania (see the Western part of Romania). These communities have formed a minority group in Romanian for a hundred years (INSSE).

The language and the culture of ethnic Hungarians in Romania are significantly different from the majority population. The other unique features of these Hungarian communities are their strong cultural, educational, labour market, and economic linkages to Hungary. All of these distinct features can have effects on how the Romanian settlements with a significant Hungarian population are organising their society and economy, running public institutes, managing development. The appearance of Hungarian inhabitants may contribute to social and cultural diversity of the settlements; and diversity can increase the creativity and economic 
prosperity of communities (Alesina \& La Ferrara, 2005; Putnam, 2007, Bellini et al., 2013). Therefore, the baseline research question of this study is whether Hungarian minority communities have specific public development patterns comparing to the Romanian majority.

Urban settlements with a Hungarian majority are proper fields to study the potentially distinct social and economic development patterns of the Hungarian communities in Romania. On the one hand, due to the democratically elected decision-making bodies of the Romanian settlements (local self-governing bodies), the management and the development of the Romanian settlements with a Hungarian majority population can be dominated by their local Hungarian communities. On the other hand, the above mentioned possibly different features of the Hungarian communities in Romania should be especially characteristic in the urban settlements having more legal and financial possibility and responsibility for organising public matters than the other settlements. Therefore, the scope of this study is the urban settlements of Romania with a Hungarian majority. This study is aiming to explore the most characteristic social and economic features of these settlements. This study applies a quantitative analysis based on a wide range of statistical data.

\section{LITERATURE REVIEW}

Research on relations between ethnicity and economy has evolved in recent decades (Csata, 2015). The correlations between ethnic diversity and economic development are fundamentally determined by the development of democratic institutions (Alesina \& La Ferrara, 2005). Deeper democratic culture and more developed economy like in the US (Putnam, 2007) or Western European countries (Bellini et al., 2013) are rather able to host ethnic diversity in a productive way, and reduce its possible negative effects (Collier, 2000). This is different in case of less development countries, e.g. in Africa (Easterly \& Levine, 1997; Alesina \& La Ferrara, 2005). Besides this, cultural characteristics and social organizational patterns of different minorities living even in the same region can lead to different economic strategies and outcomes (Aldrich \& Waldinger, 1990; Light \& Gold, 2000). In case of our research we defined diversity at country and regional level, when an ethnic minority (Hungarians) of a country (Romania) can dominate decisions on development of some of its own communities. Therefore, we searched for communities where the ethnic minority community can form a majority during democratic decisions (so not searching for diversity inside the communities). So we examined the cities in Romania having an ethnic Hungarian majority.

Studying minority Hungarians has resulted in numerous scientific works for the past hundred years. Most of the current researches examine minority Hungarians in the fields of ethnography 
or ethnic geography (Varga, 1998; Nyárádi, 2003; Balizs \& Bajmóczy, 2012), demography (Kapitány, 2013; Veres, 2015; Tátrai, 2017), and educational research (Bartha, 2014; Papp, 2016; Pusztai \& Márkus [Ed.], 2017). We have much less knowledge on social and economic conditions of Hungarian communities, although these topics have started to get into the academic and policy focuses recently. The regional differences of entrepreneurial activity of Translyvania has demonstrated that the ethnic composition of villages has no effect on the variance of the number of businesses per 1000 people (Csata, 2012). However, at the level of counties and smaller regions, in some places there are differences that are connected to the varying ethnic composition of the villages (for example, in Mureș [Maros] county). A further analysis shows that in smaller towns in Szeklerland (a region of Transylvania, located in the middle of Romania inhabited mostly by ethnic Hungarians), where the Hungarians form majority, there is a greater entrepreneurial activity (Csata et al., 2011). The general social stratification is that Translyvanian Hungarians are under-represented in the participation of tertiary educations (Veres, 2015), in the class of intellectuals and experts (Veres, 2013) and in better payed and high status occupations (technical, commercial, executive position) (Csata, 2017). All of these features can result in a 14\% less average income in the case Hungarians comparing to the Transylvaninan Romanians (Kiss, 2014). So the social features of the Hungarian minority communities reflect in most of the cases less development potential than the majority society. The territorial aspect of the ethnic and socio-economic relations has barely targeted directly in researches. So the question can be raised whether similar week development positions can be explored in the case of ethnic Hungarian regions and settlements as it could be detected in the case of Hungarian minority society.

Besides these, it is worth shortly overviewing the literature dealing with the development of the settlement structure and the urbanisation of Romania (Benedek, 2006; Zamfir et al., 2009; Csák, 2009, 2015; Săgeată, 2010; Mitrică, 2014; Mitrică, Săgeată, \& Grigorescu, 2014; Dumitrache et al., 2016). Sandu (2017) has provided probably the most comprehensive multidimensional study on the development at settlement level in Romania lately (defining "LHDI index", the latest version of this index measures the local human development of settlements with 30-30,000 inhabitants). There are also some examples of multidimensional analysis on the development of the western border area (Nagy, 2014) or Moldavian towns (Covasinau \& Covasnianu, 2014). Nevertheless, the ethnic pattern as an approach has not really been applied yet in these urban development related studies.

\section{Urbanization and ethnic stratification in Romania}

As part of the practical content of the study, it is worth knowing the characteristics of Romania's urban network and its urbanization history, which also has an important dimension of social stratification that correlates with ethnicity and ethnic affiliation. Out of Romania's 13,000 
settlements, 320 have urban status, with a total of 12 million people, $54 \%$ of the country's total population. Romania is one of the least urbanized countries in the European Union with this rate. Nevertheless, as the balance of the last hundred years (1912-2011), the number of urban populations increased by 9 million and quadrupled in the country (Mitrică, 2014). One of the most significant results of this urbanization process was the change in the ethnic structure of cities, more specifically the urbanization of the Ethnic Romanians (Varga, 1998).

Right after World War (WW) I, the significantly enlarged Romania was still mainly rural, with only $20 \%$ of the total population living in 112 towns (Mitrică, 2014; Boia, 2015). Ethnic Romanians did not form a majority in many of the cities, especially not in the newly incorporated Western part of the country (Transylvania). While Romanians formed majority only in some small towns, in larger urban settlements the majority belonged to Hungarians and/or Germans (and Jews) (e.g. in Cluj-Napoca [Kolozsvár], Arad, Oradea [Nagyvárad] or Timişoara [Temesvár]). This partially spatial (related to urban-rural gap) and partially ethnic structure was well reflected also in the data on literacy and occupational structure: the more urbanized minorities had better values (Kiss, 2014).

Between the two WW, strengthening Romanian middle class became an important governmental goal in Romania in parallel with increasing the ethnic Romanian character of the Romanian cities (Brubaker et. al., 2011). In spite of the moderate increase of the urbanization rate in Transylvania, the proportion of Romanian and Hungarian city dwellers became almost equal by the end of the interwar period. After the Second World War, the Communist takeover entailed radical change in the urbanization. As a result of the centrally managed strong industrialization and so-called "systematization", Romania's urban population increased by 230\% between 1948 and 1992, while the country's total population grown only by $44 \%$. The country's urbanization rate rose from $23.4 \%$ to $54.3 \%$, while the number of cities increased from 153 to 260 (Varga, 1998). The population of Transylvanian cities has increased by almost $400 \%$, and the number of Romanian city dwellers became 20 times higher at the end of this period. In the meanwhile, the proportion of Hungarians among city dwellers fall back from $38 \%$ to $20 \%$ (Varga, 1998), while Jewish and German communities had practically collapsed due to the losses of the World War II and emigration (Varga, 1998; Veres, 2015).

The radical socio-economic changes following the collapse of socialism have also given a new direction to urban development. The market economy-based competition among settlements became a leading force behind urbanization. Economic and social changes have led to a strong differentiation of the settlement network and have led to a dramatic change in the spatial structure of cities in Romania, too (Kovács, 2002). Larger cities (especially those which have a geographically advantage by being on the western regions) have become clear winners after the transition period, while small and medium-sized cities, declining industrial centres and 
most of the mining towns were unable to adapt to the new economic and social conditions. Deurbanization had become a general phenomenon, in which, besides the welfare suburbanisation, migration began from deindustrialized cities of depressed areas into the villages and rural areas (Benedek, 2006), in parallel with an overall strong decline of Romania's population. The uneven socio-economic territorial development of Central and Eastern European countries after 1990 and joining the EU (Salamin, 2015) can be also experienced in Romania, However, in this country the urban-rural dichotomy remained less sharp than elsewhere in the macro region till the 2000s (Jeney, 2010). These processes were reflected in the population change of cities: except 30 settlements, the population of all towns (larger cities too) were shrinking (1992-2011) (Mitrică, 2014). Policies had a direct effect on the urbanisation after the transition: 60 settlements mostly with only several thousand inhabitants were granted urban status to cope with the declining level of urbanization and the lack of urban areas identified by Law 351/2001. In 2007, the urbanisation level represented the highest value ever recorded in Romania (55.2\%); it decreased to 54\% by 2011 (Mitrică, 2014). Besides the continuous urban shrinking the most common phenomenon of the urbanization of nowadays Romania is the rapidly developing residential and commercial suburbanization started from 2000s. The process has been characterized by legislative ambiguity and institutional instability, which has indirectly led to an uncontrolled suburban sprawl in case of many Romanian cities (Dumitrache et. al., 2016). With all of these phenomena the urbanization in Romania occur in three different form in the new millennium: with new towns in areas characterized by lack of urban settlements; former rural communes in the proximity of regional poles, and de facto towns in the proximity of regional poles (Csák, 2015). Today, the Romanian urban network consists of 225 small cities (inhabitants $<20,000), 75$ medium sized cities $(20-100,000$ inhabitants), and 19 large cities (inhabitants $>100,000$ ), and a metropolis (Bucharest). The 320 cities lie spatially unevenly, there significant differences in the level of the urbanization between counties (Mitrică, 2014).

Shrinking of Hungarian urban population continued during this latest transformation of the Romanian city network. A large emigration affected the Hungarian communities especially the urban communities between 1987 and 1991 (Veres, 2015). The proportion of Hungarians decreased, and the remaining majority disappeared in all large cities. There was a similar trend in many of those 20 small and middle-sized cities in which Hungarians still form majority: this majority has become very weak in some of them. Now, more than half of the Transylvanian Hungarians live in villages (Péti et al., 2018), while Romanians has become the most urbanized ethnic group (Kiss, 2014). 


\section{DATA AND METHODS}

The socio-economic development of cities with Hungarian majority are compared to similar sized cities of Romania, so cities with lower than 60,000 inhabitants are the subjects of the analysis based on data from the 2011 Romanian census. (The population of the most populous city with Hungarian majority is Sfântu Gheorghe [Sepsiszentgyörgy], is 56,000, while the smallest one, also the smallest town in Romania, is Băile Tușnad [Tusnádfürdö] with only 1641 dwellers.) This population category includes 284 towns/cities from 320 settlements of Romania with urban status. In the study, the Hungarian majority cities are those, which the absolute number of ethnic Hungarians exceeded the number of other ethnic groups (basically Romanians) based on the most recent census in Romania and have urban status (oraş and municipiu are the two categories of urban statuses in Romania). This means, that beside absolute majority cities, there are cities, in which the Hungarians only have relative majority and they technically can be considered as an ethnically mixed settlement.

The aim of this study to measure the current level of development. The development level is a multi-dimensional and multi-indicatoral phenomenon (Nemes Nagy (Ed.), 2005), therefore 25 indicators relevant to socio-economic development were compiled from secondary data in order to measure the socio-economic position of the cities involved. The data were collected from three Romanian data sources. ${ }^{22}$ Most of the data are from year 2014, but some of them were taken from the census in 2011. Indicators describing the same scope have been classified into components expressing certain aspects of socio-economic development. A Bennett complex indicator ${ }^{23}$ were calculated for each component (with converting values to logarithmic scale in case of some indicators based on practical considerations) (Tab. 1).

Cities have become comparable in each dimension (a dimension is represented by a component), and an overall socio-economic development was also calculated based on all the indicators used in the analysis. Results refer to the general development characteristics of the Romanian cities and towns with a population less than 60.000 . The outcomes also focus on the development position of cities and towns with a Hungarian majority inside the aforementioned segment of the Romanian urban network. The development level of some cities with a Hungarian majority in enlarged regions inhabited mostly by Hungarians (see the larger cities in Szeklerland and the western group of the Hungarian urban settlements in Crișana [Partium]) was analysed in a more detailed way comparing the values of these settlements to the values of other cities and towns in their neighbourhood with similar size and with a Romanian majority. ${ }^{24}$

\footnotetext{
${ }^{22}$ INSSE TEMPO, INSSE eDEMOS, 2011 Romanian census

${ }^{23}$ Bennett's Complex Indicator calculation is based on a special value for the data series (maximum in this case). The calculated percentages ensure the aggregation of data consisting of several different units of measurement.

${ }^{24}$ For the comparison to "larger cities of Szeklerland", these Romanian majority cities are those, which have population between 30,000 and 60,000 and are situated in the neighbouring counties of Szeklerland and for the
} 
Table 1 The list of indicators and component used in the analysis

Component

\begin{tabular}{|c|c|}
\hline \multirow{4}{*}{$\begin{array}{l}\text { Human resources, } \\
\text { demography }\end{array}$} & 1. Population growth rate in the past 3 years per 1000 inhabitants (2014) \\
\hline & $\begin{array}{l}\text { 2. Share of active age population (15-64 years) in total population (\%) } \\
\text { (2014) }\end{array}$ \\
\hline & $\begin{array}{l}\text { 3. Number of college and university graduates per } 1000 \text { inhabitants (2011 } \\
\text { census) }\end{array}$ \\
\hline & $\begin{array}{l}\text { 4. The ratio of the young population aged } 0-14 \text { as a percentage of the active } \\
\text { population aged } 15-64(2014 \mathrm{log})\end{array}$ \\
\hline \multirow{3}{*}{$\begin{array}{l}\text { Economic } \\
\text { environment, } \\
\text { employment }\end{array}$} & $\begin{array}{l}\text { 5. Average number of enterprises per } 1000 \text { inhabitants in the past } 3 \text { years } \\
\text { (2014) }\end{array}$ \\
\hline & 6. Total income (Lei) per employee in the active enterprises (2014) \\
\hline & $\begin{array}{l}\text { 7. Unemployment rate }(\%) \text { - Employed people in the population aged } 15- \\
64 \text { per } 100 \text { inhabitants }(2014)\end{array}$ \\
\hline \multirow{6}{*}{ Living Standards } & 8. Housing density - Dwelling per person (2014) \\
\hline & 9. Average dwelling size $\left(\mathrm{m}^{2}\right)(2014)$ \\
\hline & $\begin{array}{l}\text { 10. Number of new dwellings in the past } 3 \text { years averaged per } 10,000 \\
\text { dwellings }(2014 \log )\end{array}$ \\
\hline & 11. Households with central heating (\%) (2011 census) \\
\hline & 12. Households equipped with kitchen (\%) (2011 census) \\
\hline & 13. Households equipped with bathroom (\%) (2011 census) \\
\hline \multirow{4}{*}{$\begin{array}{l}\text { Human } \\
\text { Infrastructure }\end{array}$} & $\begin{array}{l}\text { 14. Number of educators and teachers per } 1000 \text { inhabitants in the age group } \\
0-24(2014)\end{array}$ \\
\hline & $\begin{array}{l}\text { 15. Number of classrooms per } 1000 \text { inhabitants in the age group } 0-24 \\
(2014)\end{array}$ \\
\hline & 16. Number of hospital beds per 1000 inhabitants (2014) \\
\hline & 17. Number of general practitioners per 1000 inhabitants (2014) \\
\hline \multirow{4}{*}{ Infrastructure } & 18. Sewerage $(\%)$ (2011 census) \\
\hline & 19. Drinking water supply (\%) (2011 census) \\
\hline & 20. Ratio of roads with solid cover (\%) (2014) \\
\hline & 21. Green area per inhabitants $\left(\mathrm{m}^{2}\right)(2014)$ \\
\hline \multirow{4}{*}{ Tourism, Culture } & 22. Number of tourists per 1000 inhabitants $(2014 \log )$ \\
\hline & 23. Numbers of night spent per tourist $(2014 \log )$ \\
\hline & 24. Number of museum visitors per 1000 inhabitants (2014 log) \\
\hline & $\begin{array}{l}\text { 25. Number of visitors to cultural institutions (e.g. theatre, concert) per } \\
1000 \text { inhabitants }(2014 \log )\end{array}$ \\
\hline
\end{tabular}

\section{General overview of the 20 Hungarian majority cities}

Out of the 631,000 Hungarian urban population of Romania (2011), only 227,000 live in those cities where Hungarians form majority. The Eastern group of the Hungarian urban settlements (14) are situated in the historical Szeklerland (Székelyföld), while the Western group of the Hungarian urban settlements lays in Crișana (Partium) (Fig. 1). Generally, Transylvania's spatial structure of development can be characterized by a dual spatial structure where the counties of South-Transylvania (together with Bihor ([Bihar]) are more developed, and the

comparison to Hungarian majority cities of Crișana (Partium), are those which have population between 5,000 and 20,000 and are situated in Bihor (Bihar), Satu Mare (Szatmár) or Sălaj (Szilágy). 
counties which are situated in North-Transylvania are less developed (Benedek, 2016). The Hungarian majority cities, with three exceptions, are situated in the peripheral side of this spatial structure. The largest settlement with a Hungarian majority, Sfântu Gheorghe (Sepsiszentgyörgy) has the highest position in the hierarchy among the 20 cities with a Hungarian majority. Sfântu Gheorghe is considered a regional pole according to the Romanian territorial policy (Conceptul Strategic de Dezvoltare Teritoriala Romania 2030, 2008) with a population of over 50,000. Miercurea Ciuc (Csíkszereda) and Odorheiu Secuiesc (Székelyudvarhely) belong to the category of supra-regional poles, while the remaining seventeen cities with Hungarian majority can be classified only as local poles suitable for serving only the surrounding rural areas. The population of ten cities out of those seventeen do not even exceed 10,000 .

Figure 1 Population and ethnic structure of Hungarian majority cities in Romania (2011)

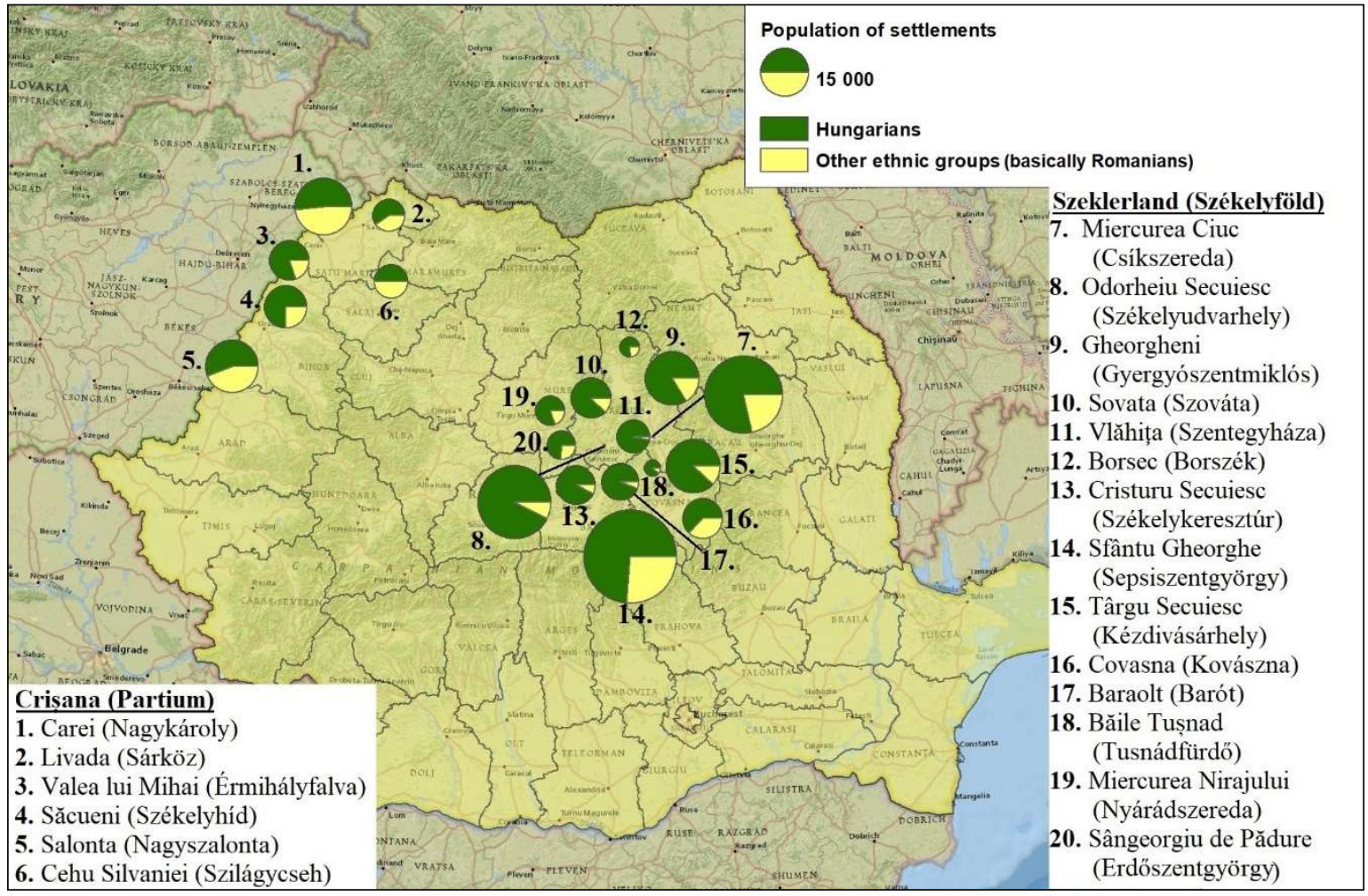

The Hungarian majority cities belong to the small- and medium-sized cities of urban network of Romania. The lowest adaptability to the altering economic environment can be observed at the medium-city level (20-100,000 inhabitants), since many of these cities had developed as a result of forced industrialization during the socialist era, and their economic structure is often one-sided (Benedek, 2006). Small towns (inhabitants $<20,000$ ) have the highest representation in the urban network of Romania (70\%). Although cities established in the last hundred years have increased the number of small towns, their weight in the urban population reduced: while 
the $2 / 5$ of the urban population lived in small towns in 1912 , nowadays only $1 / 8$. Still, the role of the small towns is important in the settlement network, linking the cities to the countryside (Zamfir et al., 2009; Csák, 2009). The weight and role of small towns in the network of settlements depend also on their functions (industrial, agro- industrial, agricultural, touristic) and geographical location (located in the centre of a rural area or near a larger city) (Zamfir et al., 2009).

Sfântu Gheorghe (Sepsiszentgyörgy), Miercurea Ciuc (Csíkszereda) and Odorheiu Secuiesc (Székelyudvarhely) belong to the county-seat type of medium-sized cities. These three cities had a significant administrative role even before World War I. Sfântu Gheorghe (Sepsiszentgyörgy) lies in the neighbourhood of Brașov (Brassó) with a population of 250 thousand, which has a great impact on its potential agglomeration area, economic strength and the level of its regional functions. Miercurea Ciuc (Csíkszereda) is a school centre and university town, with strong county-seat function set. Odorheiu Secuiesc (Székelyudvarhely) is not a county seat but fits into a group of typically medium sized smaller weight but significant industrial, commercial and educational centres with county-level functions.

Târgu Secuiesc (Kézdivásárhely), Gheorgheni (Gyergyószentmiklós) and Cristuru Secuiesc (Székelykeresztúr) are multifunctional cities with old traditions and have medium-city role in Szeklerland. All the three cities had strong industrial and commercial functions, and their local role in commerce is still significant (Horváth (Ed.), 2003).

In the category of small towns, the number of towns with touristic functions is significant. The touristic function of Sovata (Szováta) and Băile Tuşnad (Tusnádfürdő) is based on spas. Covasna (Kovászna) is one of the most important centres of health and medical tourism. Borsec's (Borszék) touristic (and partly industrial) activities are linked to mineral water and mining. Baraolt (Barót) is a small mining town (lignite), which city category facing serious economic and social problems since the transition (Horváth (Ed.), 2003). Vlăhiţa (Szentegyháza), Miercurea Nirajului (Nyárádszereda) and Sângeorgiu de Pădure (Erdőszentgyörgy) are considered as regional microcenters inhabited by few thousand people in Szeklerland. The latter two just received their city status at the new millennium.

The region of Crișana (Partium) became target of a more extensive industrialization and urbanization than the aforementioned region, Szeklerland (Mezei, 2009). As a result, the Hungarian majority of the region encompassing this Western group of the Hungarian urban settlements is not so dominant as in the case of Szeklerland, and this Hungarian majority territory is also more scattered. Carei (Nagykároly), the former seat of a county has a significant service and industrial function but had lost the function of an administrative centre, resulting in a very modest increase in population over the past 100 years. Salonta (Nagyszalonta), Săcueni 
(Székelyhíd), Valea lui Mihai (Érmihályfalva), Livada (Sárköz) and Cehu Silvaniei (Szilágycseh) fall into the category of small towns.

\section{RESULTS}

\section{Human resources, demography}

The aim of 'human resources, demography' complex indicator is to express the qualitative and quantitative characteristics of human capital. The values spread between 38.52 and 85.36, the average of the data series is 64.15 . The standard deviation of the data series is relatively low; most of the cities have a value close to the average. The difference is mainly due to the rate of population growth and the rate of the graduate population. Cities, which lie in the agglomeration zone of Bucharest (Popești-Leonerdi, Bragadiru, Otopeni), county seats (Zalău [Zilah], Vaslui, Slobozia, Alexandria), some municipiums (Beiuș [Belényes], Câmpina] and even small towns (Beclean [Bethlen], Ghimbav [Vidombák]) have higher complex indicator than the average in the city category due to the high or outstanding value of aforementioned two indicators separately or together (Fig. 2).

Figure 2 Human resource, demographic complex indicators of the 284 cities as a percentage of the average (2014)

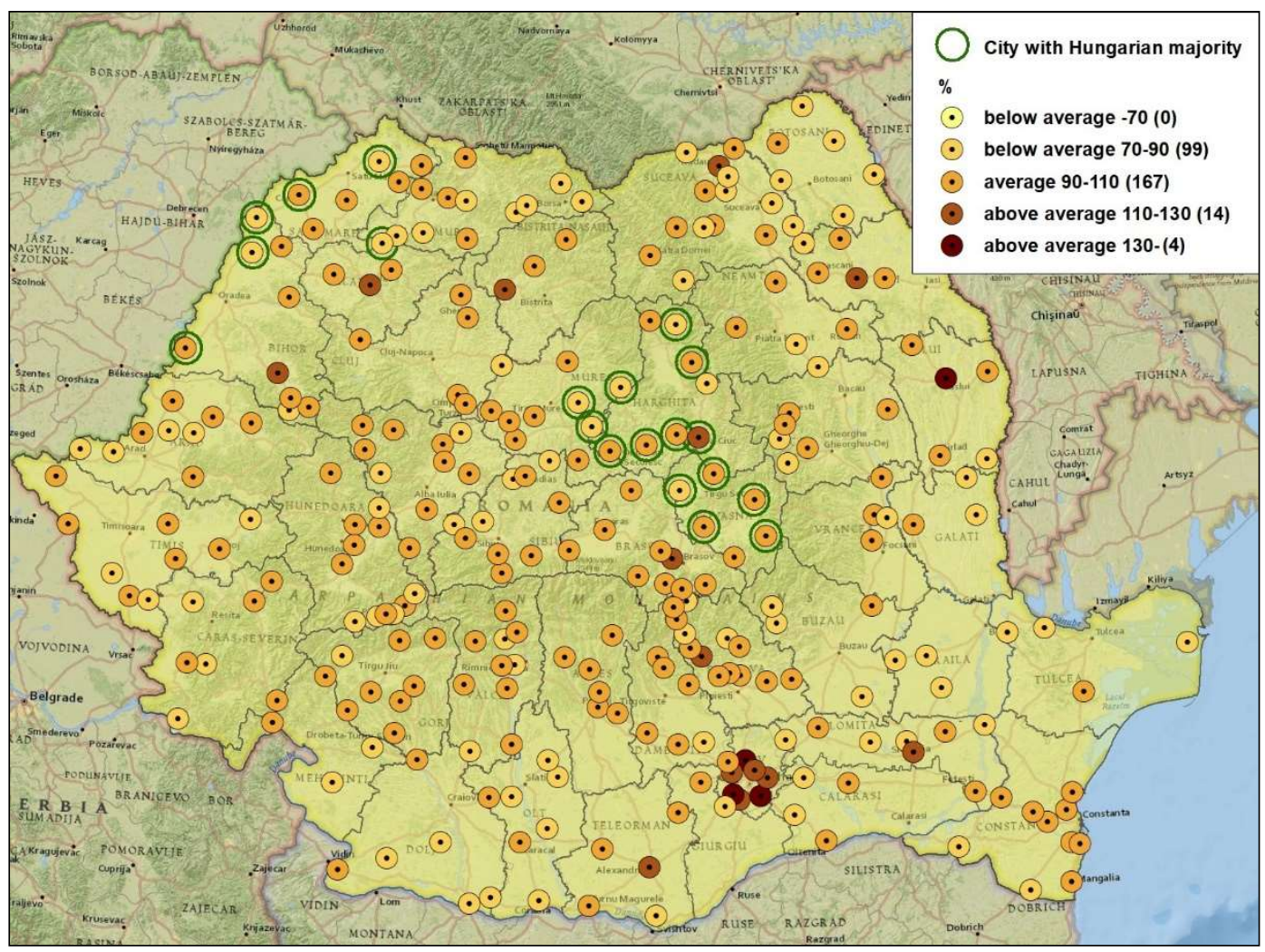


Among the Hungarian majority cities, only Miercurea Ciuc (Csíkszereda) belongs to this outstanding category. The cities with Hungarian majority are in rather disadvantageous position within the component: $45 \%$ of these cities have values lower than the average, while this proportion is only about $33 \%$ in case of the cities with Romanian majority. $50 \%$ of the Hungarian majority cities are on the average, while this rate is higher $(60 \%)$ in the case of cities with a Romanian majority. The most important drivers behind the low indicator values of the Hungarian settlements are the low rate of graduates, the negative population growth rate, and the disadvantageous age structure of Hungarian majority cities. In regional context, Miercurea Ciuc (Csíkszereda) in Szeklerland has outstanding values comparing to its neighbouring cities with Romanian majority, not like in the case of the Western group, in Crișana (Partium) where cities having lower complex indicator values are the ones with a Hungarian majority (Fig. 3). The key component behind these results is the high and low rate of graduates in each region.

Figure 3 Human resource, demographic complex indicators of Hungarian majority cities and their similar-sized neighbours with Romanian majority in Transylvania (Erdély) and Crișana (Partium)

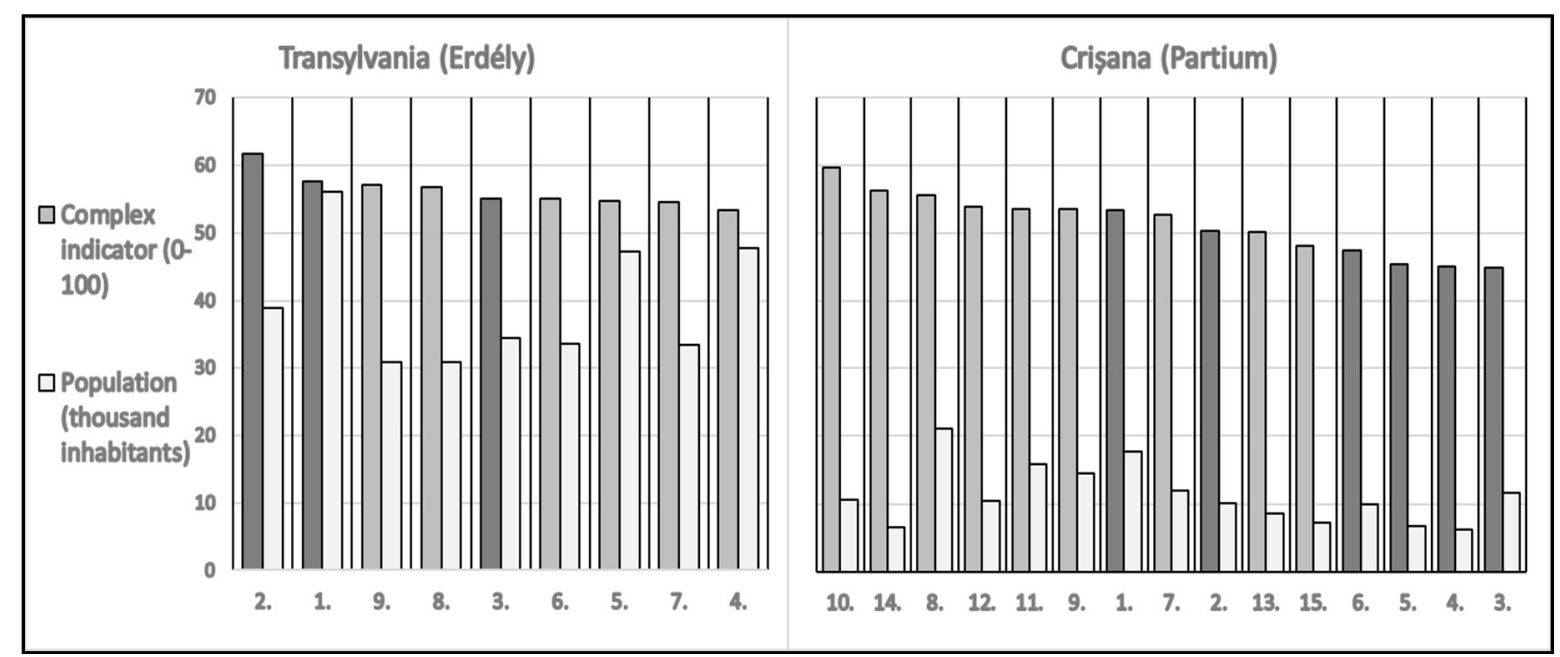

Transylvania (Erdély): 1. Sfântu Gheorghe (Sepsiszentgyörgy), 2. Miercurea Ciuc (Csíkszereda), 3. Odorheiu Secuiesc (Székelyudvarhely), 4. Turda (Torda), 5. Mediaș (Medgyes), 6. Dej (Dés), 7. Reghin (Szászrégen), 8. Săcele (Négyfalu), 9. Făgăraș (Fogaras)

Crișana (Partium): 1. Carei (Nagykároly), 2. Salonta (Nagyszalonta), 3. Săcueni (Székelyhíd), 4. Valea lui Mihai (Érmihályfalva), 5. Cehu Silvaniei (Szzilágycseh), 6. Livada (Sárköz), 7. Marghita (Margitta), 8. Șimleu Silvaniei (Szilágysomlyó), 9. Negrești-Oaș (Avasfelsőfalu), 10. Beiuș (Belényes), 11. Jibou (Zsibó), 12. Aleșd (Élesd), 13. Tășnad (Tasnád), 14. Ștei (Vaskohsziklás), 15. Ardud (Erdöd)

\section{Economic environment, employment}

The 'economic environment, employment' complex indicator is to describe the performance of local economy and the employment opportunities. The values spread between 32.89 and 73.67 , the average of the data series is 44.38. The differences in this component are not high in case of the most elements, the values of most cities are similar to the average or situated slightly below. The outstanding values of cities in the agglomeration of the capital can be explained by 
high entrepreneur density and employment. There are other settlements with high complex indicator values where there is a major employer (e.g. oil refinery in Năvodari or Dacia factory in Mioveni) (Fig. 4).

Figure 4 Economic environment, employment complex indicators of the 284 cities as a percentage of the average (2014)

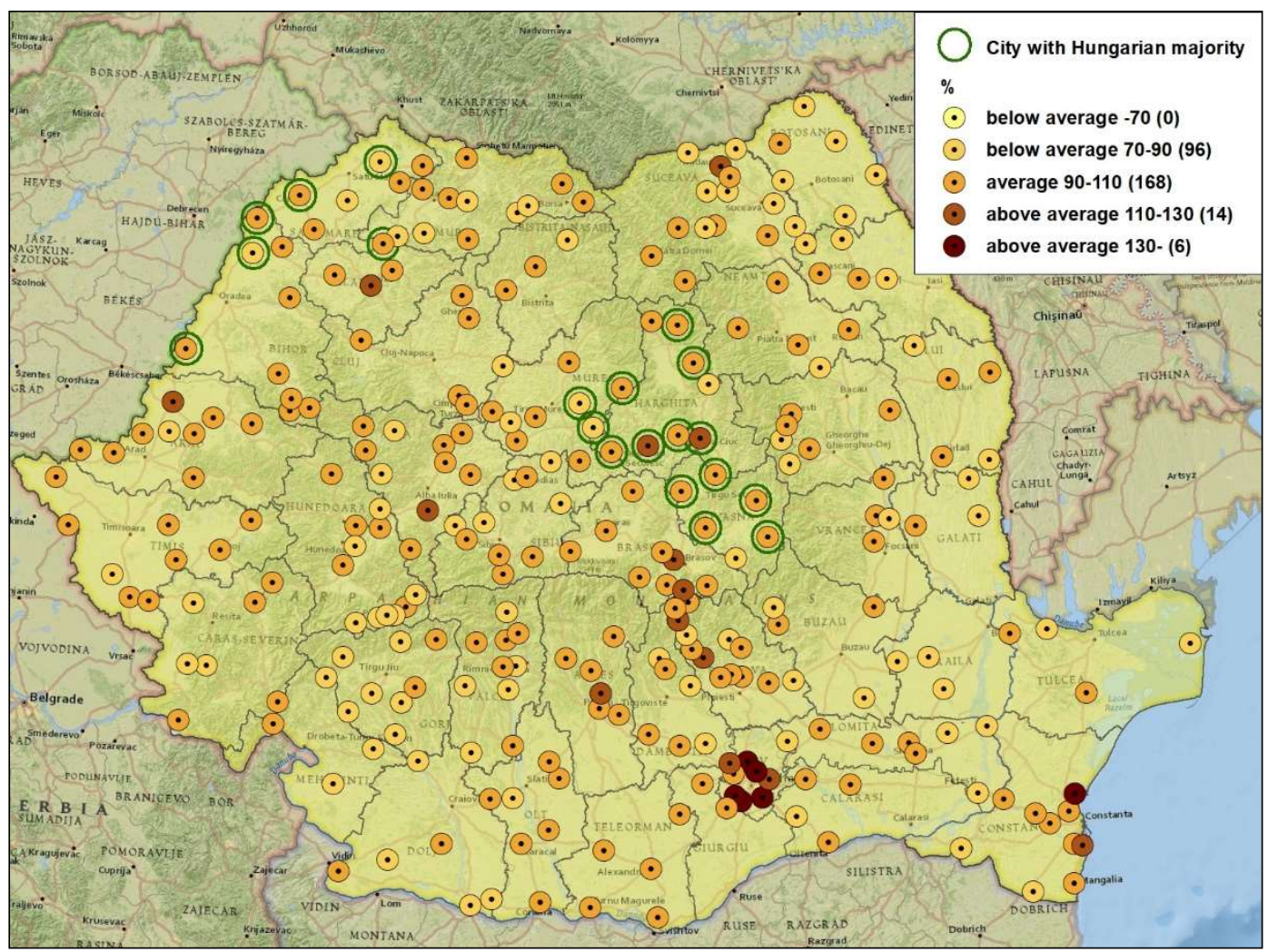

Cities with Hungarian majority can be estimated to have more advantageous positions than those of having Romanian majority. Only $20 \%$ of them have value below average compared to the Romanian majority cities (35\%). 70\% of the Hungarian cities (14 cities) have values around the average, and two of these cities (10\%) have complex indicator value above the average, while in the case of Romanian majority cities these values are only $58 \%$ and $7 \%$. Miercurea Ciuc (Csíkszereda) and Odorheiu Secuiesc (Székelyudvarhely) are the two Hungarian cities with the highest complex indicators. They also have higher indicator values than the similarsized Romanian majority cities in their neighbourhood. The main reason behind this is the higher entrepreneurial activity of the Hungarian majority cities (while their income per employee values are lower). In the case of the Western group of the Hungarian urban settlements the economic indicator of Carei (Nagykároly) and Salonta (Nagyszalonta) can be considered similar to the neighbouring same sized settlements with a Romanian majority. Other towns with a Hungarian majority in this group have lower values than almost all of their 
neighbours (Fig. 5). The main reason for this is the low entrepreneurial activity compared to the regional level.

Figure 5 Economic environment, employment complex indicators of Hungarian majority cities and their similar-sized neighbours with Romanian majority in Transylvania (Erdély) and Crișana (Partium)

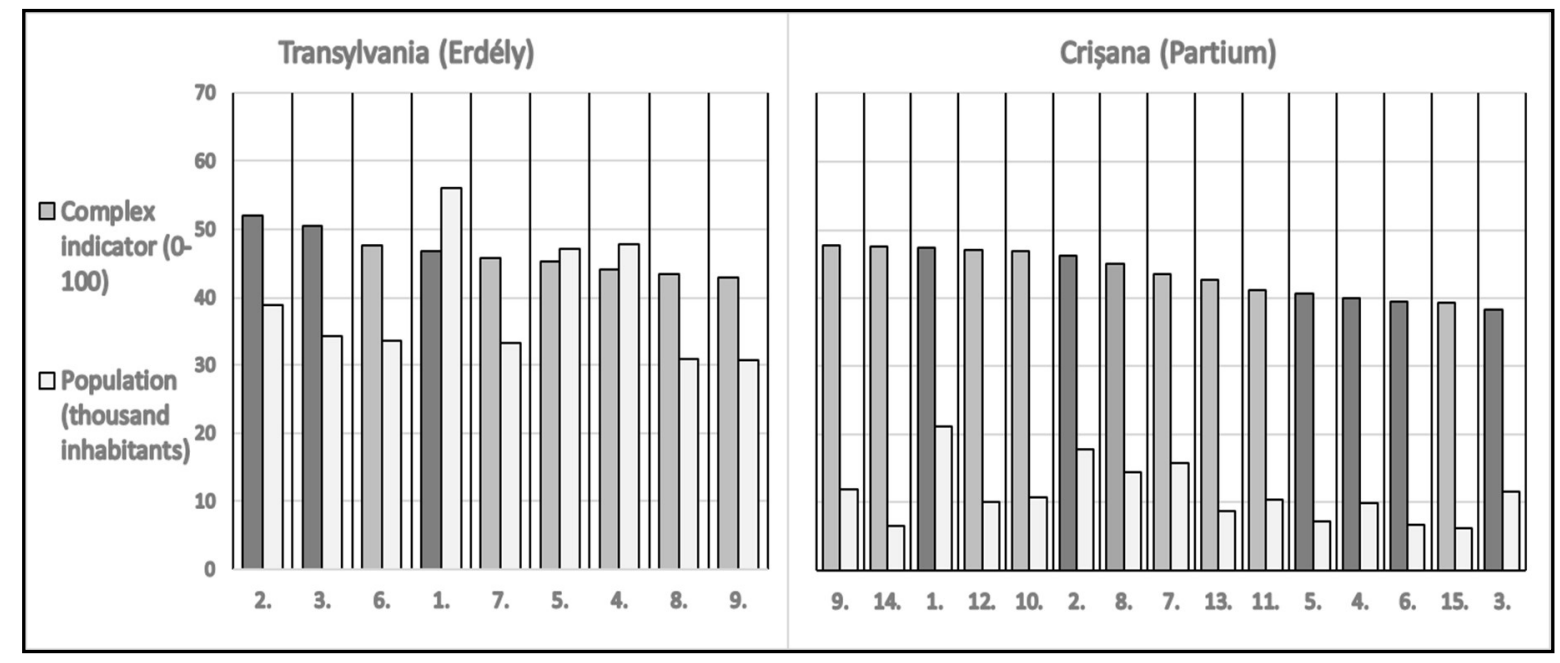

(See the numbers for each city in Figure 3)

\section{Human Infrastructure}

The 'human infrastructure' component aims to measure the accessibility and quality of public and human public services, education and health care available to urban populations. The component is also an indicator of the central functions possessed by a city, as the examined public services are usually available beyond the boundaries of a given settlement. The values spread between 14.21 and 74.69 , the average of the data series is 33.18. Obviously, not every settlement can have a hospital, special medical facility, or a major educational institution, so the elements are spread over a wide range compared to the average (Fig. 6). In most cases, the small urban settlements with significant regional educational level (Beiuș [Belényes], Horezu) or a hospital/health care institution (e.g. Nucet [Diófás], Covasna [Kovászna]) have the highest values. The lowest values can be found in cities where the educational or healthcare capacities are relatively weaker, and/or the general practitioner system is overloaded (e.g. Borșa, Mizil). Low indicator values can be resulted also by the vicinity of a large city or being a member of a conurbation (e.g. Petroșani basin) (Fig. 6).

Hungarian majority cities have the most advantageous positions in the case of this component. Only $10 \%$ of them have values below average compared to $42 \%$ of the Romanian majority cities. $55 \%$ of Hungarian majority cities are among the above-average cities, while only $31 \%$ of the Romanian majority group. These good positions are mainly due to the good quantitative and qualitative conditions of their educational institution. On a regional scale, 
Miercurea Ciuc (Csíkszereda) and Odorheiu Secuiesc (Székelyudvarhely) have outstanding high values compared to the six Romanian majority cities. (It is worth mentioning also Cristuru Secuiesc (Székelykeresztúr), which has the highest indicator of the Hungarian majority cities.) This complex indicator values in case of the western group of the Hungarian urban settlements are mostly similar to their Romanian majority neighbours (Fig. 7).

Figure 6 Human infrastructure complex indicators of the 284 cities as a percentage of the average (2014)

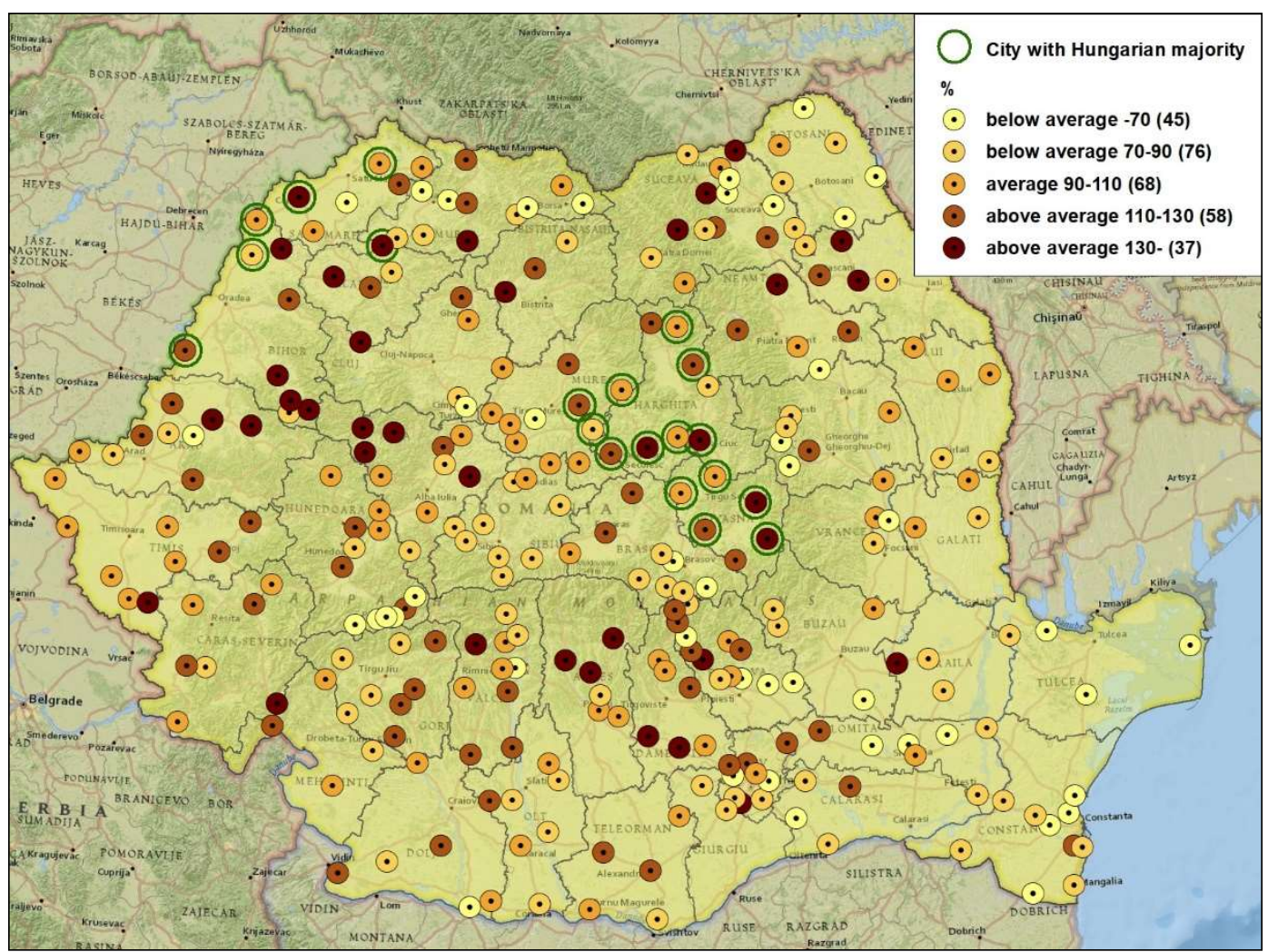

Figure 7 Human infrastructure complex indicators of Hungarian majority cities and their similarsized neighbours with Romanian majority in Transylvania (Erdély) and Crișana (Partium)

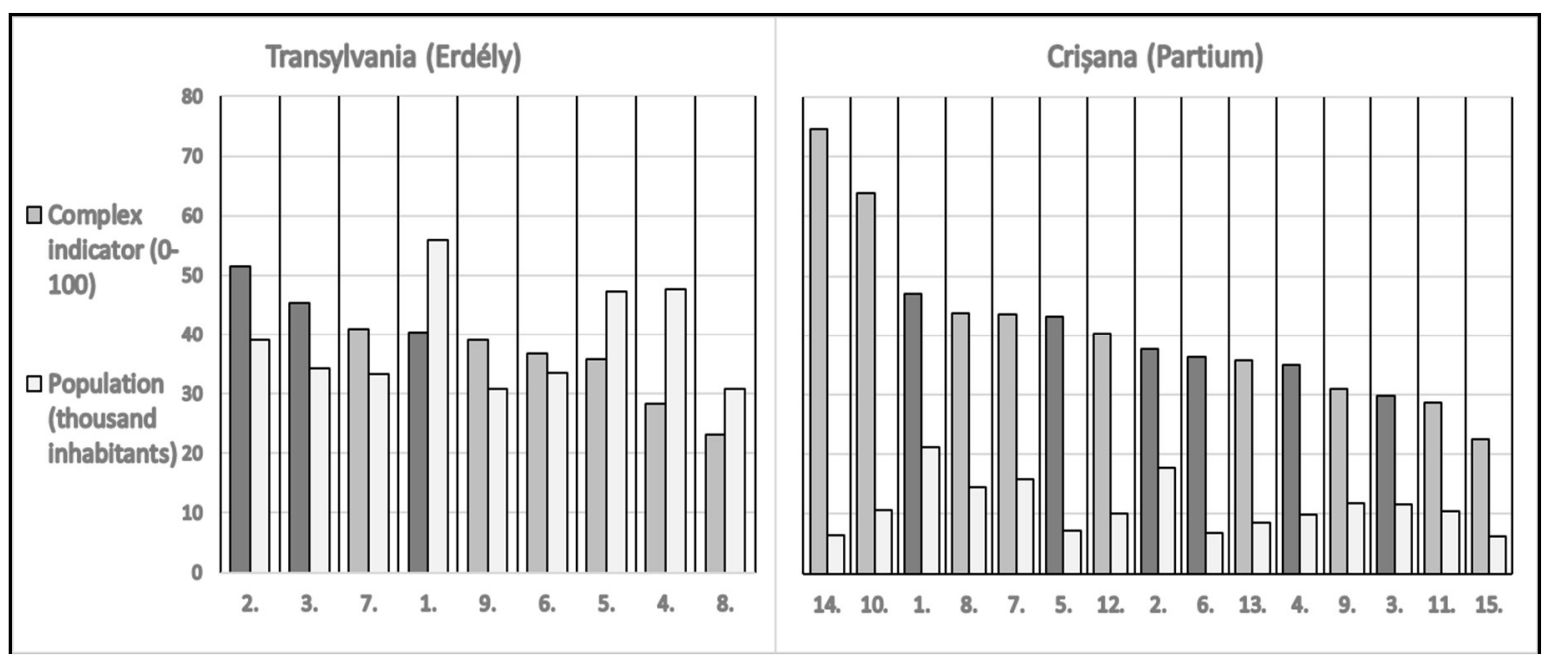

(See the numbers for each city in Figure 3 on page 10) 


\section{Living standards}

'Living standards' are described by indicators representing housing stock and comfort level of households. The values spread between 34.33 and 89.16, the average of the data series is 64.15 . In this case, the standard deviation is also high, primarily due to the comfort level of households. Almost exclusively only small urban settlements can be found below the average. Except for a few cases, the lowest indicators are typical for non-Transylvanian small towns. High values occurs at towns in agglomerations (Bucharest, Brașov [Brassó], Constanța) as well as at some municipiums (Zalău [Zilah], Gherla [Szamosújvár]], and popular towns, touristic destinations (Sinaia, Băile Tușnad [Tusnádfürdő]) (Fig. 8).

Figure 8 Living standards complex indicators of the 284 cities as a percentage of the average (2014)

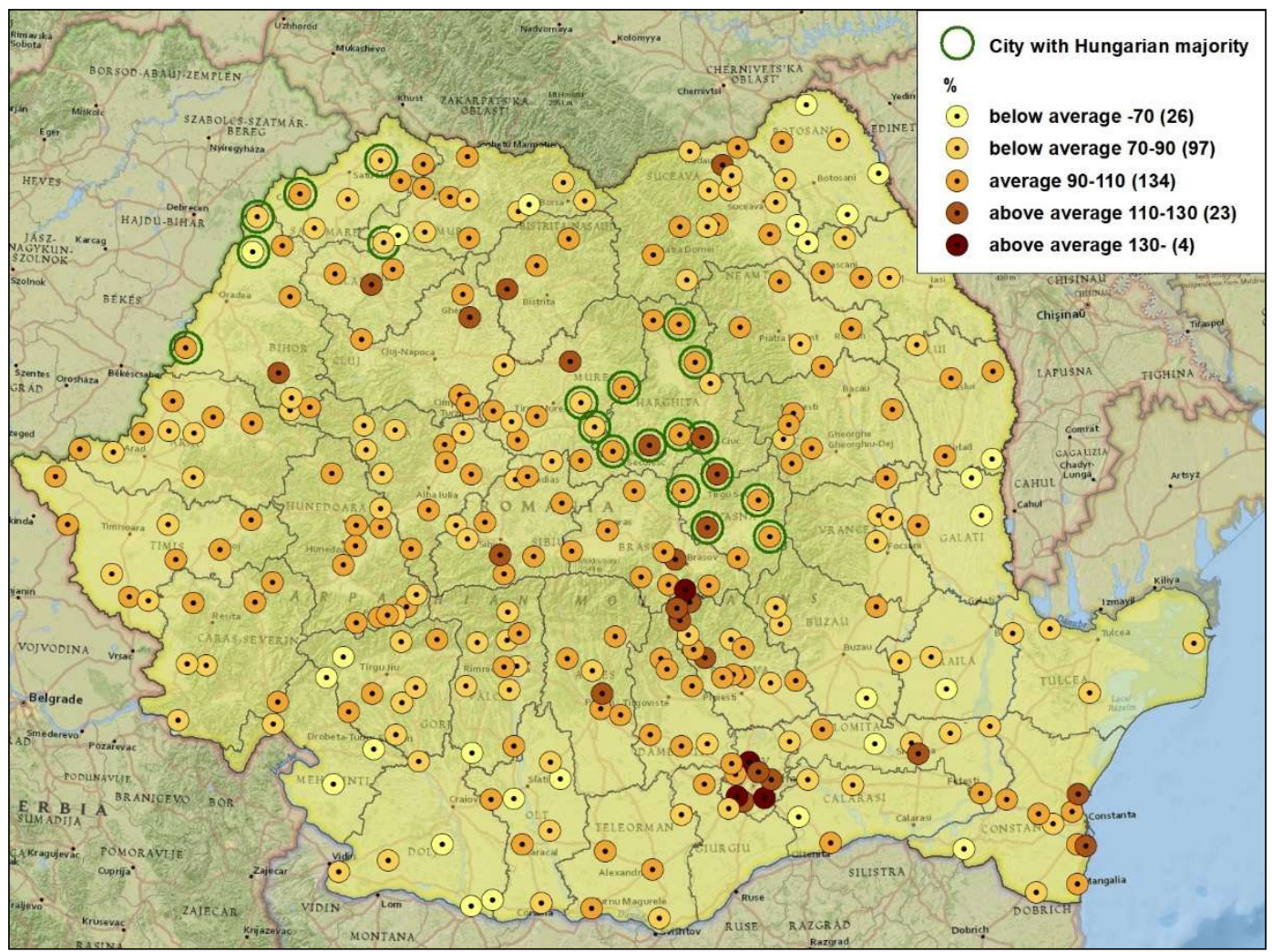

The 'living standards' of the Hungarian majority cities are better than the Romanian majority cities. $30 \%$ of the Hungarian majority cities are below the average, $20 \%$ of them are above the average (these values are $44 \%$ and $9 \%$ in the case of the Romanian majority cities). In Transylvania, the larger urban settlements of Szeklerland are in leading positions among the other medium-sized cities of the encompassing region. They have great advantages in the comfort level of households especially. In Crișana (Partium), towns with a majority of 
Hungarian population have lower values than their neighbours with Romaninan majority except Carei (Nagykároly) and Salonta (Nagyszalonta) (Fig. 9). The value of this complex indicator at Săcueni (Székelyhíd) is particularly low even on the national level.

Figure 9 Living standards complex indicators of Hungarian majority cities and their similarsized neighbours with Romanian majority in Transylvania (Erdély) and Crișana (Partium)

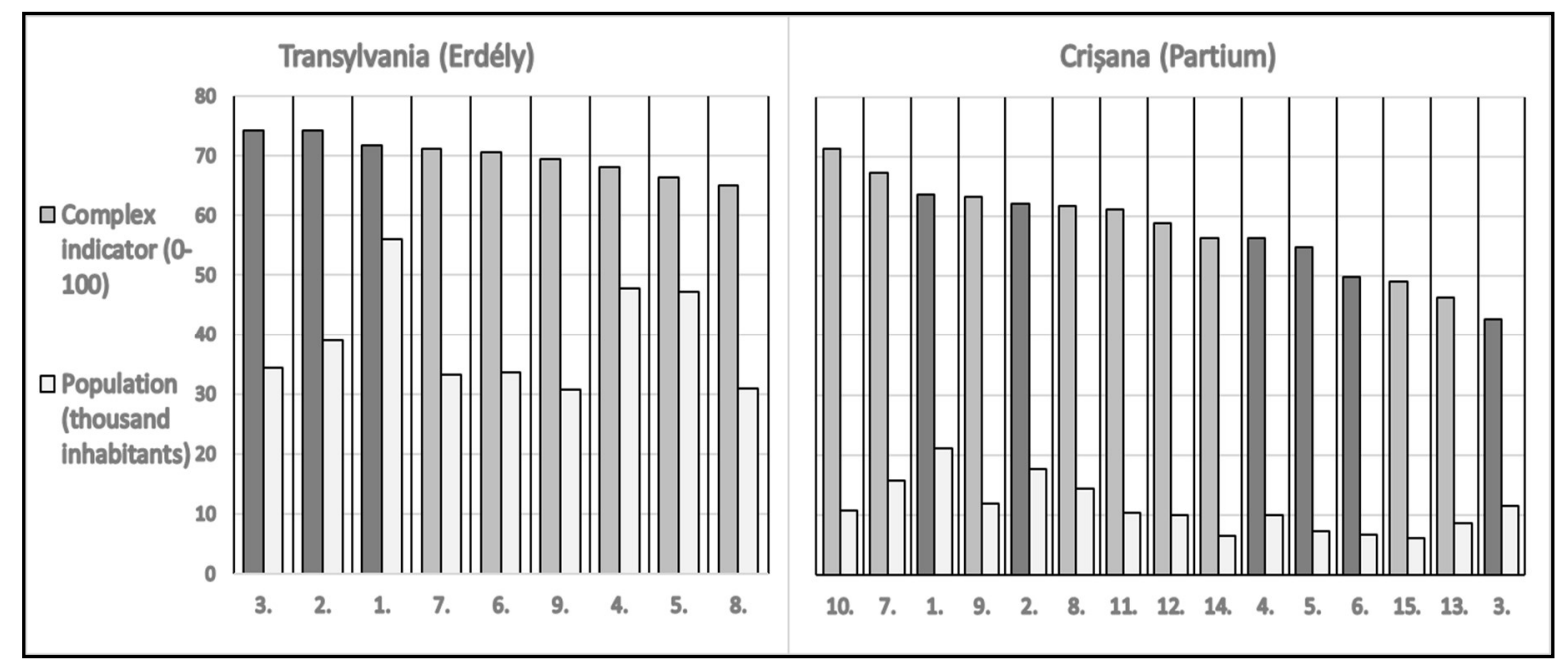

(See the numbers for each city in Figure 3.)

\section{Infrastructure}

The 'infrastructure' component measures the level and quality of public infrastructure and communal services. The values of the complex indicator are distributed between 21.25 and 89.97, the average of the data series is 66.80 . There are significant differences between cities in terms of all infrastructure indicators. The cities with the highest scores show a heterogeneous picture by their size and function, but they are consisting of mostly Transylvanian cities, while the cities significantly lagging behind are almost exclusively outside of Transylvania (Fig. 10).

The Hungarian majority cities seem to have a bit advantageous level of development within the small and medium city network (inhabitants $<60,000$ ) in case of this component, too. Only $20 \%$ of them are below the average, while in the case of Romanian majority cities this value is $40 \% .30 \%$ of them are above the average, which is few percent higher than in the case of the Romanian majority cities. However, there are basically negligible differences between the Hungarian and Romanian majority elements in Szeklerland and its neighbourhood counties. (Here, the small Băile Tușnad (Tusnádfürdő) is in a leading position among the Hungarian majority cities.) Most of the Hungarian majority towns near the Western border are situated in the middle section in the order of development of infrastructure level. However, Livada 
(Sárköz) and mainly Săcueni (Székelyhíd) are far behind the average development level of the small towns of the region (Fig. 11).

Figure 10 Infrastructure complex indicators of the 284 cities as a percentage of the average (2014)

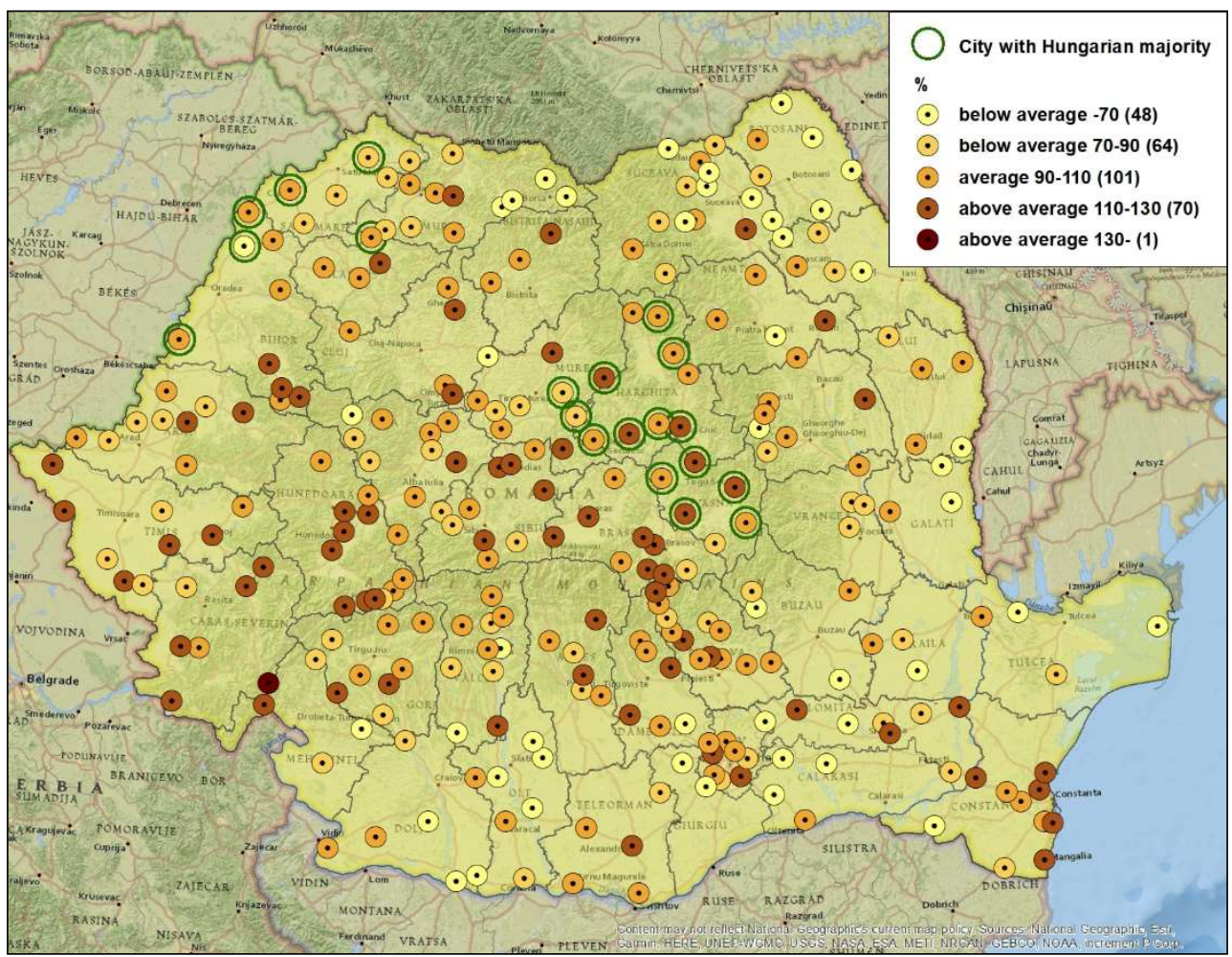

Figure 11 Infrastructure complex indicators of Hungarian majority cities and their similar-sized neighbours with Romanian majority in Transylvania (Erdély) and Crișana (Partium)

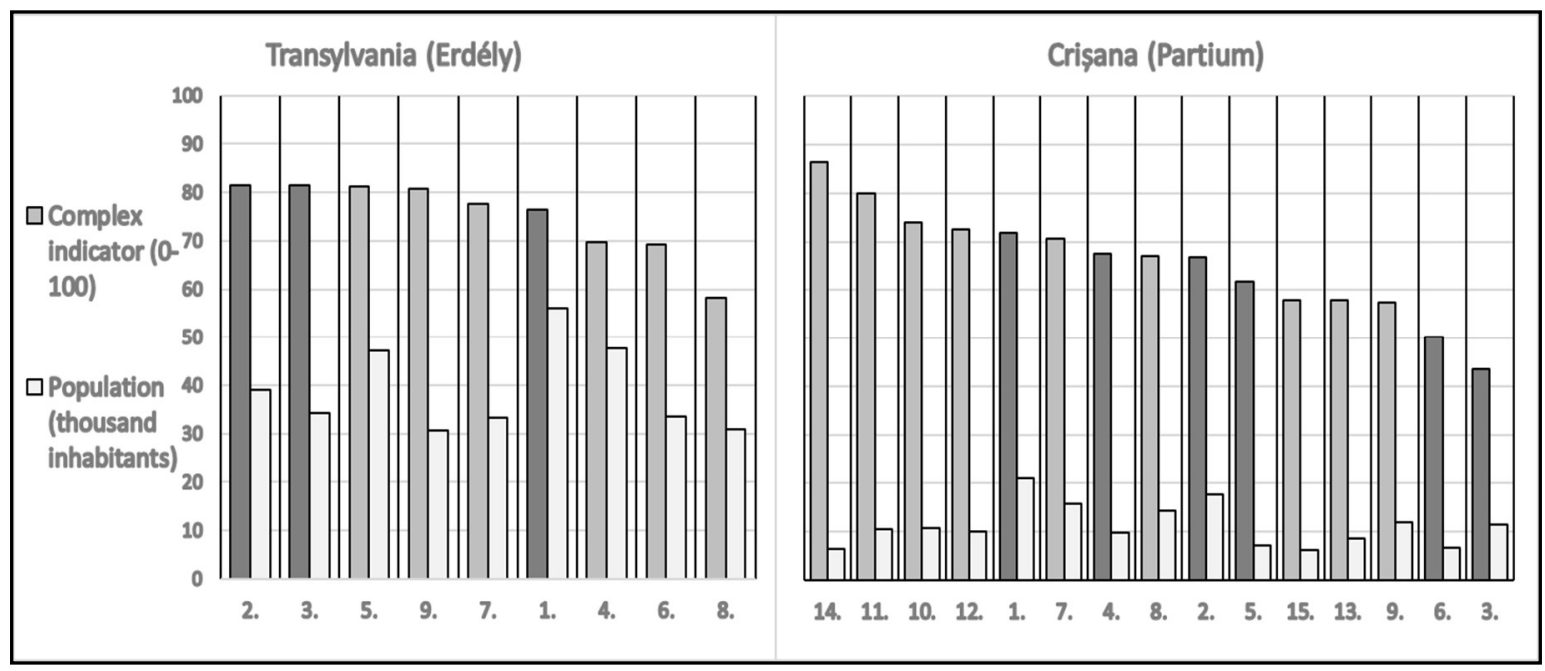

(See the numbers for each city in Figure 3.) 


\section{Tourism, culture}

This component is to measure the role of cities in tourism and organising cultural life. It focuses on the existence of outstanding touristic and cultural functions at regional or national level. Nearly half of the cities involved into the analysis have only minimal tourism, still the average value is 57.90 (due to indicators used in the calculation). The vast majority of the 284 cities are lagging far behind from this average value, and there are only a few cities that have high or non-zero values for all indicators used in the component. As a result, there are no cities with an indeed outstanding value compared to the average. The highest indicators are obviously in the case of small towns with touristic and cultural functions (e.g Buziaș [Buziásfürdő], Sinaia) as well as municipium with central functions (e.g. Slobozia, Zalău [Zilah]) (Fig. 12).

Figure 12 Tourism, culture complex indicators of the 284 cities as a percentage of the average (2014)

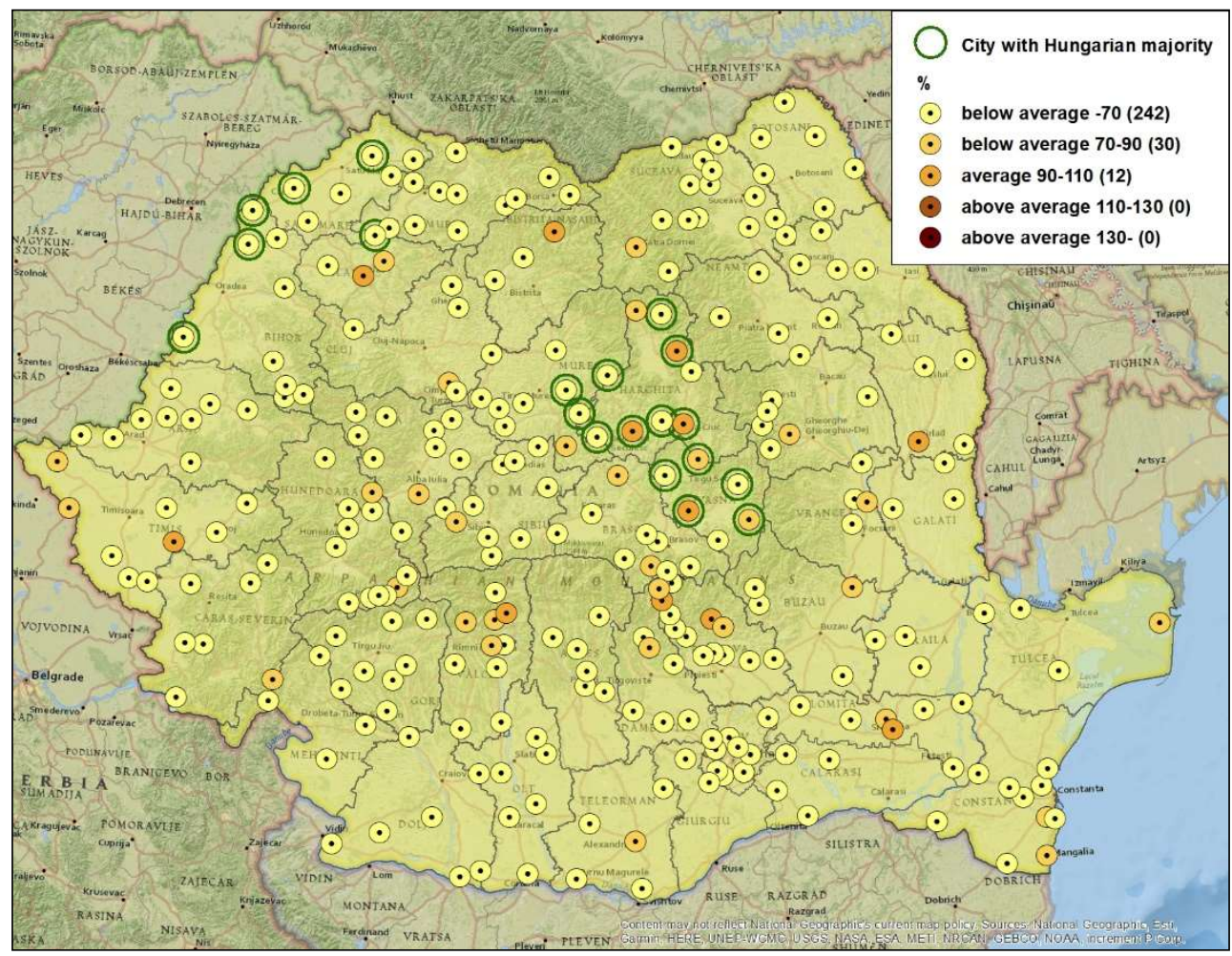

The medium-sized Hungarian majority cities are clearly overrepresented in this group. Out of the 12 cities with the highest score, four are the most populous Hungarian majority cities of Szeklerland. In addition to the relatively significant amount of tourism associated with these cities, a sound cultural consumption (theatres, concerts) - which otherwise would be more typical in really large cities - is also can be observed in these Hungarian cities. The latter case is probably due to the absence of a large city in the counties of these Hungarian cities (as in the 
case of Vaslui and Ialomița counties). It can also be due to the unique cultural role of these Hungarian cities organising the cultural life of the Hungarian speaking communities throughout Romania. Not surprisingly, these cities have higher indicator values than the medium-sized Romanian majority cities, which are situated in the closer neighbourhood of large cities with cultural institutions. In some cases of the small towns of Crișana (Partium), there are settlements with no tourism in the case of both ethnic city groups. However, where tourism is statistically presented, the Hungarian majority cities belong to the set of less visited settlements except Carei (Nagykároly) and Salonta (Nagyszalonta) (Fig. 13).

Figure 13 Tourism, culture complex indicators of Hungarian majority cities and their similarsized neighbours with Romanian majority in Transylvania (Erdély) and Crișana (Partium)

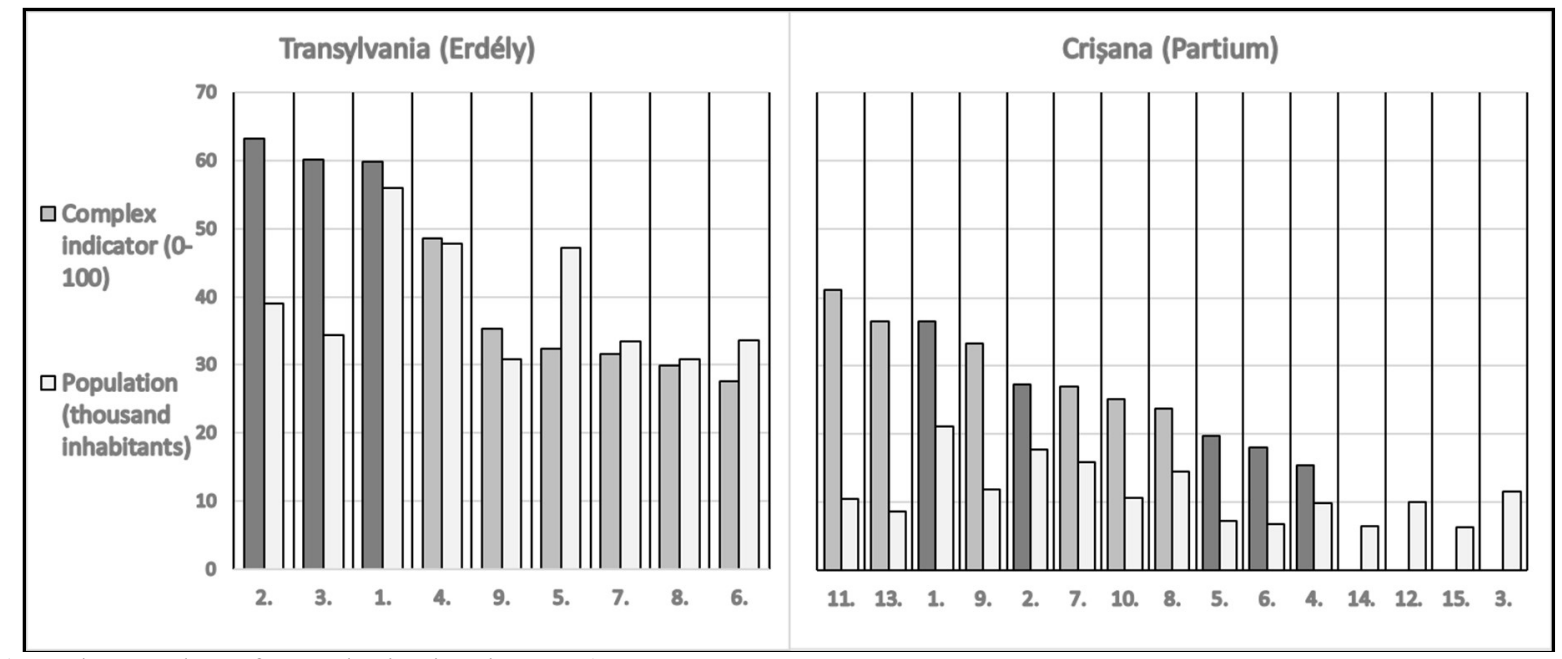

(See the numbers for each city in Figure 3.)

\section{Socio-economic development}

Aggregated 'socio-economic development' is a complex indicator calculated by using all indicators, determines the general social-economic development. The values of the complex indicator are distributed between 26.18 and 64.00 with an average of $54.50 .60 \%$ of the cities are below the average, except for 14 all of them are small towns. The most underdeveloped are the towns outside of Transylvania with some Transylvanian settlements (e.g. in Maramureș [Máraramos] county). The seven most advanced elements of the 284 cities are as follows in ascending order: Sfântu Gheorghe (Sepsiszentgyörgy), Sinaia, Popești-Leordeni, Zalău (Zilah), Otopeni, Odorheiu Secuiesc (Székelyudvarhely), and Miercurea Ciuc (Csíkszereda) with the highest complex indicator (Fig. 14). 
Figure 14 Socio-economic development complex indicators of the 284 cities as a percentage of the average (2014)

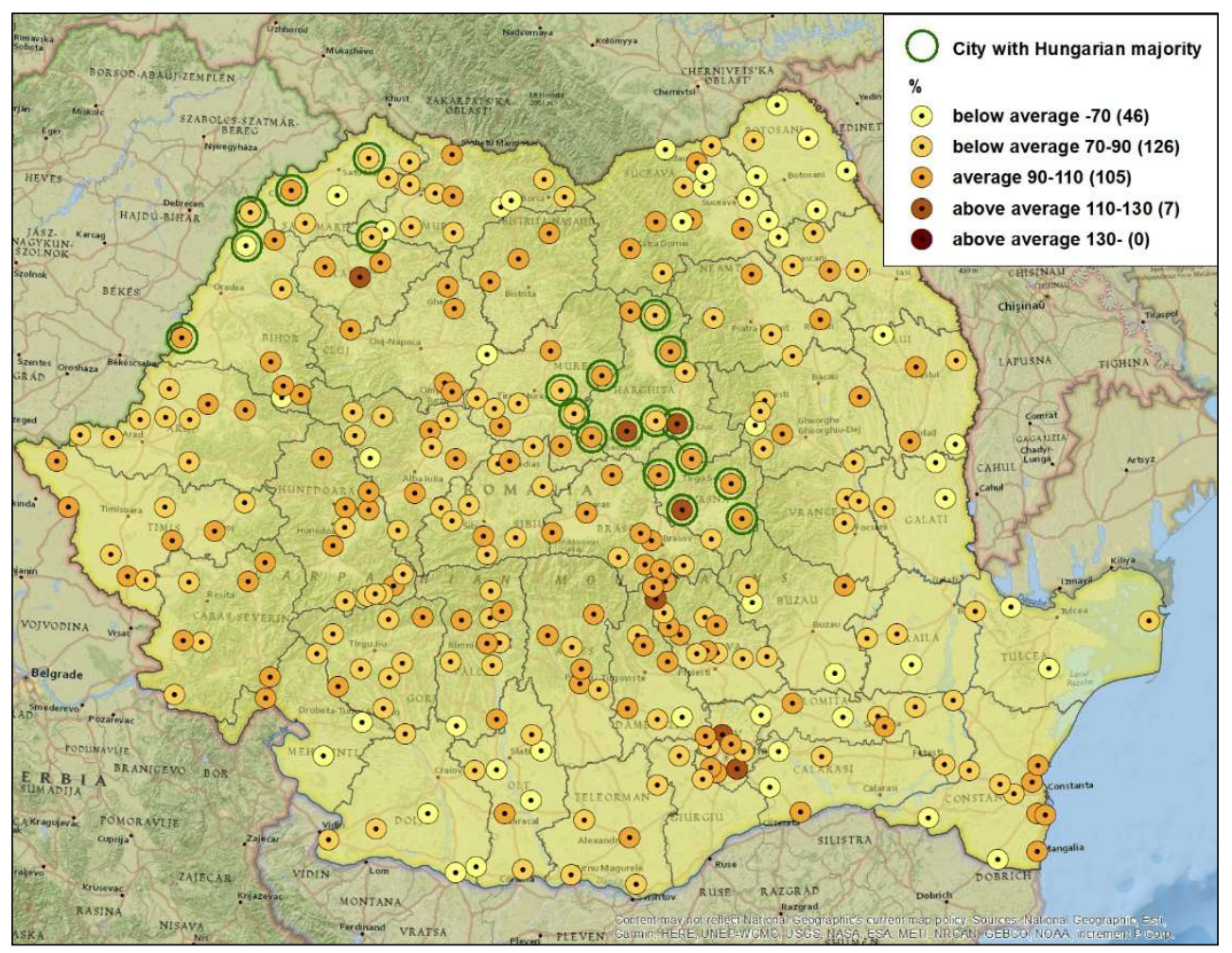

Among the not mentioned other Hungarian majority cities nine are on the average and eight are below the average. This proportion values reflect more advantageous positions than the case of Romanian majority cities. Of course, at the territorial level, the complex indicator values of the aforementioned Hungarian majority cities of Szeklerland are higher than in the case of the cities with Romanian majority in the encompassing region. In the case of the western group of the Hungarian towns and cities, in Crișana (Partium), the small towns with Hungarian majority is are lagging behind in a regional comparison, the only exceptions are Carei (Nagykároly) and Salonta (Nagyszalonta) (Fig. 15). The complex indicator of Săcueni (Székelyhíd) is particularly low, which is one of the least developed cities on the national level too. 
Figure 15 Socio-economic development complex indicators of Hungarian majority cities and their similar-sized neighbours with Romanian majority in Transylvania (Erdély) and Crișana (Partium)

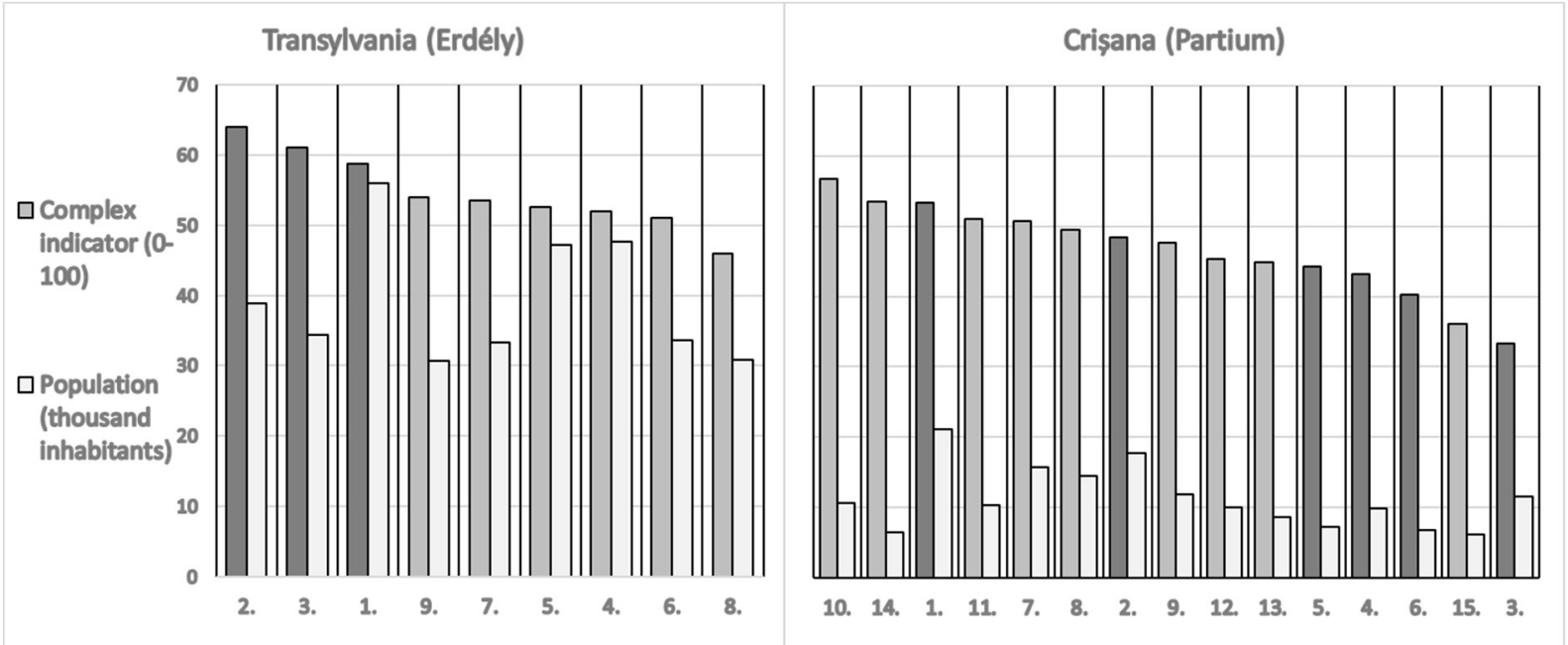

(See the numbers for each city in Figure 3.)

\section{Transylvania and Hungarian majority as city cluster forming drivers}

The current study is not focused on applying other methodologies than above mentioned ones but the encompassing research project conducted also a cluster analysis (with Ward method) (Barna \& Székelyi, 2008) on the same data sets (284 urban settlements, 6 complex indicators calculated from 25 statistical indicators). This analysis resulted in three distinct clusters representing cities above the average development level, and three other clusters representing cities in an underdeveloped position. Introducing just very briefly some further relevant results of this analysis it is worth mentioning that Transylvanian settlements are in greater number in the more developed clusters, while elements of the less-developed clusters consist of cities out of Transylvania in higher proportion. (The least developed cluster consists of small towns of out of Transylvania almost exclusively.) 11 urban settlements with a Hungarian majority belong to the better developed clusters (almost all of them are part of the Eastern group of these cities, in Szeklerland); and one of the more developed clusters has a quite high proportion (20\%) of these Hungarian cities in Szeklerland. The Western group of the urban settlements with a Hungarian majority belong almost exclusively to the less developed clusters.

\section{CONCLUSIONS AND DISCUSSION}

In this study, all 284 Romanian cities with less than 60.000 inhabitants were described by seven complex indicators, focusing especially on the distinction between cities with a Hungarian majority and other cities. Presence of Hungarian majority can result in a more advantageous position for the cities in all development components especially in the case of Szeklerland's 
cities (in the middle of Romania, at the Eastern part of Transylvania). The generally disadvantageous social and economic positions of the Hungarian minority communities inside the Romanian society (described by the current literature) does not necessarily reflected also in the development position of the cities inhabited mostly by Hungarians, especially not in the case of the cities of Szeklerland. An exception is the human resource and the demographic component, which coincides with the overall disadvantageous demographic situation of the Hungarian minority in Transylvania.

There are significant differences between the 20 Hungarian majority cities within each component. Most of the cities of Szeklerland (in the eastern part of Transylvania, in the middle of Romania) have more advantageous indicators than the national average. On the one hand, this could be explained by the remoteness of larger cities, as big city functions appear also in these smaller settlements. On the other hand, this eastern group of the Hungarian urban settlements are located in an almost homogenously Hungarian region (Szeklerland) which large enough to form a single economic-social structure, a functional area reaching possibly a critical mass for providing certain human and cultural services (and forming eligible demand for providing these services in Hungarian). This is not the case with the western group of the Hungarian urban settlements where the mostly Hungarian functional area surrounding the urban settlements is fragmented and much smaller. These Hungarian cities of the ethnically more mixed - but in general also more developed - Western border region are mostly lagging behind the neighbouring other small towns, but some of them are even below the national average. Another interesting result of the analysis, that the Western group of Hungarian majority cities in the most cases are less developed than their similar population sized cities in Szeklerland in spite of their more favourable western positions being part of the more developed western regions of the country.

\section{REFERENCES}

Aldrich, H. \& Waldinger, R. (1990). Ethnicity and Entrepreneurship. Annual Review of Sociology 16. 111-135.

Alesina, A. \& La Ferrara, E. (2005). Ethnic diversity and economic performance. Journal of Economic Literature 43(3) 762-800.

Balizs, D. \& Bajmócy, P. (2012). A magyarországi és erdélyi városok etnikai homogenizációjának néhány aspektusa a 20. században. Közép-Európai Közlemények 5(3-4), 18-19, 127-136

Barna, I. \& Székelyi, M. (2008). Túlélőkészlet az SPSS-hez - Többváltozós elemzési technikákról társadalomkutatók számára. Budapest: Typotex Elektronikus Kiadó Kft., 453

Bartha, Z. (2014). Az iskolaválasztás motivációs hátterének vizsgálata Erdélyben, hangsúlyosan szórványban. Magyar kisebbség, 72(2), Az anyanyelvi oktatás kérdései, 6084 
Bellini, E. \& Ottaviano, G. \& Pinelli, D. \& Prarolo, G. (2013). Cultural diversity and economic performance: Evidence from European regions In: Crescenzi, R. \& Percoco, M. (eds.) Geography, Institutions and Regional Economic Performance - Advances in Spatial Science. Springer, Berlin - Heidelberg, 121-141.

Benedek, J. (2006). A romániai urbanizáció jellegzetességei az utolsó évszázad során. In: Hajdú, Z. \& Győri, R. (Ed.), Kárpát-medence: települések, tájak, régiók, térstruktúrák. Budapest-Pécs: Dialóg Campus, 66-102

Benedek, J. (2016). Területi polarizáció és periferializáció Romániában, székelyföldi perspektívából. Magyar kisebbség, 79(1), Regionalizmus - Európában és Romániában, $77-98$

Boia, L. (2015). Cum s-a românizat România?, București: Humanitas, 144

Brubaker, R. \& Feischmidt, M. \& Fox, J. \& Grancea, L. (2006). Nationalist Politics and Everyday Ethnicity in a Transylvanian Town. Princeton-Oxford: Princeton University Press, 439

Collier, P. (2000). Ethnicity, Politics and Economic Performance. Economics and Politics, 12. 225-245

Covasnianu, A. \& Covasnianu, L. E. (2014). An urban perspective upon Moldavian settlement. From political desideratum to territorial reality. Romanian Review of Regional Studies, $10(2), 39-46$

Csák, L. (2009). Romániai kis- és középvárosok ,jelentéktelensége”. Tér és Társadalom, 23(1), 181-196

Csák, L. (2015). Long-term challenges of Romanian Urban network: Planning for regions with different background. Hungarian Studies. 29, 37-48.

Csata, Z. (ed.) (2011). Vállalkozók - elvárások, lehetőségek és nehézségek. Kutatásjelentés. Kolozsvár: Interetnikus Viszonyok Kutatóközpontja

Csata, Z. (2012). The Social Determinants of Entrepreneurial Activity in Rural Transylvania. Studia Sociologia 1, 101-124

Csata, Z. (2015). Ethnicity and Economy. A Research Agenda for Transylvania. Erdélyi társadalom, 13(3), 9-14

Csata, Z. (2017). Munkaerőpiaci egyenlőtlenségek Romániában, etnikai metszetben Erdélyi Társdalom, 15(1), 81-103

Dumitrache, L. \& Zamfir, D. \& Nae, M. \& Simion, G. \& Stoica, I. (2016). The Urban Nexus: Contradictions and Dilemmas of (Post)Communist (Sub)Urbanization in Romania. Human Geographies: Journal of Studies and Research in Human Geography. 10, 38-50

Easterly, W. \& Levine, R. (1997). Africa's Growth Tragedy: Policies and Ethnic Divisions. The Quarterly Journal of Economics. 112(4), 1203-1250

Hortváth, G. (Ed.) (2003). Székelyföld. Pécs-Budapest: Dialóg Campus Kiadó, 454

Jeney, L. (2010). Key Factors of Urban Competitiveness in East Central European Space Structure: Development Paths Of Cities And Urban Agglomerations. In: Beauclair, A (Ed.): Regional responses and global shifts: actors, institutions and organisations; Seaford: Regional Studies Association (RSA), 2010, 1-14

Kapitány, B. (2013). Kárpát-medencei népszámlálási körkép. Demográfia, 56(1), 25-64

Kiss, T. (2014). Etnikai rétegződési rendszer Erdélyben és Romániában. A magyarok társadalmi pozíciói. REGIO, 22(2), 187-245

Kovács, Z. (2002). Az urbanizáció jellemzői Kelet-Közép-Európában a posztszocialista átmenet idején. Földrajzi Közlemények, 126(1-4), 57-78

Light, I. \& Gold, S. J. (2000). Ethnic Economies. Academic Press, San Diego.

Mezei, I. (2009). Városok a magyar-román határ mentén. In: Hardi T. \& Hajdú Z. \& Mezei I. Határok és városok a Kárpát-medencében. Győr-Pécs: MTA-RKK, 239-249

Mitrică, B. (2014). Changes in the dynamics and demographic structures of the Romanian urban population. An overview of the pots-communist period. Revue roumaine de Geographie/Romanian Journal of Geography, 58(2), 201-212 
Mitrică, B. \& Săgeată, R. \& Grigorescu, I. (2014): The Romanian Urban System. An Overview of the Post-Communist Period,_Forum geografic. Studii și cercetări de geografie și protecția mediului. 13(2), 230-241

Nagy, E. (2014). Factorial analysis of territorial disparities on the Hungarian-Romanian border region. Romanian Review of Regional Studies, 10(1), 7-14

Nemes Nagy, J. (Ed.) (2005). Regionális elemzési módszerek. - Regionális Tudományi Tanulmányok, Budapest: ELTE Regionális Földrajzi Tanszék - MTA-ELTE Regionális Tudományi Kutatócsoport, 284

Nyárádi, R. K. (2003). Erdély népesedéstörténete. Budapest: Központi Statisztikai Hivatal Levéltára, 672

Papp, Z. A. (2016). Változatok erdélyi szórványoktatásra. REGIO, 4(24), 173-195

Péti, M. \& Szabó, B. \& Nagy, S. \& Csécsi, D. (2018). A külhoni magyar falvak alapvető területi mintázata és népességadatai. FALU VÁROS RÉGIÓ: 1

Pusztai, G. \& Márkus, Z. (Ed.) (2017). Szülöföldön magyarul: iskolák és diákok a határon túl. Debrecen: Debreceni Egyetemi Kiadó, 334

Putnam, R. D. (2007). E. pluribus unum: Diversity and community in the twentyfirst century. Scandinavian Political Studies 30(2) 137-174.

Săgeată, R. (2010). The Role of Political Factors in the Urbanization and Regional Development in Romania. Journal of Urban and Regional Analyses, 2(1), 81-88

Salamin, G. (2015). Transforming regional position of Central-Eastern Europe in the economic space of the European Union with special reference to Hungary. Hungarian Studies: a Journal of the International Association for Hungarian Studies and Balassi Institute, 29(1-2), 73-91.

Sandu, D. (2017). Validation of the local human development index for Romanian villages by their regional location: introducing a data basis.

Tátrai, P. (2017). A Kárpát-medencei magyar szórványok településszerkezete és főbb demográfiai jellemzői. Kisebbségi Szemle, 2017/1, 7-31

Varga, E. A. (1998). Városodás, vándorlás, nemzetiség - Adatok és szempontok az erdélyi városi térségek etnikai arculatváltásának vizsgálatához. In. Varga, E. Á. Fejezetek a jelenkori Erdély népesedéstörténetéböl. - Tanulmányok, Budapest: Püski, 180-217

Veres, V. (2013). Népszámlálás 2011: A népességszám, foglalkozásszerkezet és iskolázottság nemzetiség szerinti megoszlása Romániában. Erdélyi Társadalom 2. 23-54

Veres, V. (2015). Népességszerkezet és nemzetiség - Az erdélyi magyarok demográfiai képe a 2002. és 2011. évi romániai népszámlálások tükrében. Kolozsvár (Cluj-Napoca): Kolozsvári Egyetemi Kiadó, 263

Zamfir, D. \& Tălângă, C. \& Stoica, I. (2009). Romanian small towns searching for their identity. Journal of Urban and Regional Analysis, 1(1), 41-53

Web source:

Conceptul Strategic de Dezvoltare Teritoriala Romania 2030. Retrieved on 2019.10.10.) http://www.mie.ro/_documente/publicatii/2008/Brosura_Conc_strat_EN.pdf

Data sources (might be temporarily unavailable):

2011 Romanian census: http://www.recensamantromania.ro/rezultate-2/ (downloaded: 2019.10.10.)

INSSE TEMPO database: http://statistici.insse.ro/shop/?lang=en (downloaded: 2019.10.10.)

INSSE eDEMOS database:

http://edemos.insse.ro/portal/faces/oracle/webcenter/portalapp/pages/reportaccess.jspx? adf.ctrlstate $=20 y n u f 2$ rd $4 \&$ afrLoop $=25159782229021560 \&$ afrWindowMode $=0 \&$ afrWind owId $=$ null $\# \% 2$ Foracle $\% 2$ Fwebcenter $\% 2$ Fportalapp $\% 2 \bar{F}$ pages $\% 2$ Fhome.jspx $\% 40 \% 3 \mathrm{~F}$ adf.ctrl-state\%3D9rjvxoog_4 (downloaded: 2019.10.10.) 